\title{
Posterior Choroidal Artery
}

National Cancer Institute

\section{Source}

National Cancer Institute. Posterior Choroidal Artery. NCI Thesaurus. Code C33352.

Either of two arteries (medial or lateral) that arise from the posterior cerebral artery to supply the choroidal plexus and brainstem. 